\title{
The Role of Young Farmer Horticulture Group on Improving Entrepreneur Behavior in the Special Region of Yogyakarta Indonesia
}

\author{
${ }^{1 s t}$ Siti Nurlaela* \\ Extension and Development \\ Communication Study Program, \\ Graduate School of Universitas \\ Gadjah Mada (UGM) \\ Politeknik Pembangunan Pertanian \\ Yogyakarta-Magelang (YOMA) \\ Yogyakarta, Indonesia \\ nurlaela77yk@gmail.com
}

\author{
2nd Sunarru Samsi Hariadi \\ Extension and Development \\ Communication Study Program, \\ Graduate School of Universitas \\ Gadjah Mada (UGM), \\ Yogyakarta, Indonesia \\ sunarru_sh@ugm.ac.id
}

\author{
${ }^{3 r d}$ Alia Bihrajihant Raya \\ Agricultural Extension and \\ Communication, \\ Department of Agriculture \\ Socio-Economics, \\ Faculty of Agriculture, Universitas \\ Gadjah Mada, Yogyakarta, Indonesia \\ alia.bihrajihant.r@ugm.ac.id
}

\begin{abstract}
Entrepreneurial behavior is the key factor in the success of an agricultural business. Young farmers are expected to be able to apply entrepreneurial behavior, but most are still subsistent. Through the role of young farmers groups, it is expected that entrepreneurial behavior can be formed so that it can change the subsistence farming model into business-oriented agriculture. Horticultural agriculture is an attractive agricultural sector to study because it has characteristics that are full of high risk of loss and price uncertainty. The purpose of this study is to analyze the influence of personal characteristics of young farmers which include sex, education level, and length of business on entrepreneurial behavior, the effect of the group's role on entrepreneurial behavior, and the effect of the characteristics of young farmers and the group's role together on entrepreneurial behavior. Data collection was done by a closed questionnaire through a quantitative approach. The research location was in the horticultural center of Yogyakarta Special Region, Indonesia. Random sampling method was employed and 300 were obtained. Data analysis was performed by multiple regression analysis. Factors affecting entrepreneurial behavior (Y) include sex (X1), the education level (X2), length of business $(\mathrm{X3})$, and group role (X4) all influencing entrepreneurial behavior indicated by $R^{2}=31.3 \%, F=33,599$, at $p \leq 0.05$. The role of groups has a positive effect, the length of effort has a negative effect, while sex and education level do not affect entrepreneurial behavior $(p \leq 0.05)$. Groups are a useful tool in the process of social learning among young farmers. The government is expected to facilitate further young farmers who are just starting a business with groupbased business training and assistance to improve entrepreneurial behavior so that they become successful young farmer.
\end{abstract}

Keywords-group role, entrepreneurial behavior, young farmers, horticulture, entrepreneurs

\section{INTRODUCTION}

Youth are not interested in becoming farmer because of this profession is identical with poverty, and low income [1] [2]. This condition occurs in most parts of Asia and Africa [3] [4]. Nugroho [5] stated that the narrow ownership of land in the Special Region of Yogyakarta caused them to be poor.
Most of them became farmers because of their parents' inheritance. They apply traditional agriculture and have low entrepreneurial abilities.

In order to adopt entrepreneurial behavior in farming, a supportive environment is needed. Farmer groups are an effective means to improve the entrepreneurial behavior of young farmers, as previous researches have stated [6], [7], [8]. Based on the Regulation of the Minister of Agriculture No. 67 / Permentan / SM.050 / 12/2016, the role of farmer groups are: (a) learning class: a place for teaching and learning for their members to increase knowledge, skills in farming; (b) a vehicle for cooperation: a place to strengthen cooperation between fellow farmers; (c) production units: directed to have the ability to make decisions in determining the development of profitable production.

The group of young farmers who are peers plays a supporting environmental factor in agricultural entrepreneurship. The ability to socialize at a young age is essential for their social development [9]. Furthermore, the behavior of young farmers can be viewed from the perspective of Social Psychology. Alport [10] emphasizes the influence of the presence others on the thoughts, feelings, and behavior of individuals. The same opinion is confirmed by Kurt Lewin [11] which states that the interaction between social stimulus, in this case, the environment and the individual towards their environment, is formulated very interesting in the dynamics of individual behavior with equation $\mathrm{B}=\mathrm{f}(\mathrm{P}, \mathrm{E})$. Behavior is a function of the individual and the environment. The group of young farmers who are peers plays a supporting environmental factor in agricultural entrepreneurship. The ability to socialize at a young age is essential for their social development [9]. Furthermore, the behavior of young farmers can be viewed from the perspective of Social Psychology. Alport [10] emphasizes the influence of the presence others on the thoughts, feelings, and behavior of individuals. The same opinion is confirmed by Kurt Lewin [11] which states that the interaction between social stimulus, in this case, the environment and the individual towards their environment, is formulated very interesting in the dynamics of individual behavior with equation $\mathrm{B}=\mathrm{f}(\mathrm{P}, \mathrm{E})$. Behavior is a function of the individual and the environment. 
Based on the explanation above, this research will contribute to the role of groups in entrepreneurship and its influence on improving entrepreneur behavior. The findings of this study are expected to explain that the group's goals in the current era of information technology are still significant, and can even support an entrepreneurial abilities to be more effective in developing business. In the midst of the problem of farmers' regeneration today, strengthening young farmers can be an attraction to become successful farmers.

\section{RESEARCH METHODOLOGY}

The research location is in the horticulture area in Yogyakarta Special Region, which covers three districts; Bantul, Kulonprogo, and Sleman (Figure 1). Determination of location based on horticultural productivity data Department of Agriculture, Yogyakarta Special Region The criteria for respondents who meet the requirements this study is young farmers who are horticultural entrepreneurs with a 18-40 years and have been incorporated in groups for at least one year. The population is young farmers who are members of a group in the horticultural center village, in the three regions with the highest horticultural productivity. Sampling was done by simple random sampling on half of the members of the young farmers group, so 300 young farmers was obtained.

Data collection was employed using a closed questionnaire. Research variables consist of dependent and independent variables. The dependent variable is entrepreneurial behavior and independent variables are: the role of young farmers group, sex, education level and length of business. The role of the group are: vehicle for learning, collaboration, and building network. Entrepreneurial behavior are: identifying business opportunities, exploiting business opportunities, developing businesses, and utilizing new media for businesses.

The variables of group roles and entrepreneurial behavior are measured using a 5-score rating scale that includes; (1) Never, (2) Rarely, (3) Sometimes, (4) Often, (5) Always. Determinant factors: sex (1) for men, (0) for women, education level calculated based on years of education: Primary School (6), Middle School (9), High School (12), University (17), length business is calculated in years from the start of the business. Percentages and average scores are used to analyze the personal characteristics of young farmers, the role of groups, and entrepreneurial behavior. While the influence of determinants on entrepreneurial behavior is done by multiple linear regression analysis. The statistical model is as follows: $\mathrm{Y}=\mathrm{k}+\mathrm{aX} 1+\mathrm{bX} 2+\mathrm{cX} 3+\mathrm{dX} 4$

Description:

Y : Entrepreneurial behavior

$\mathrm{k}$ : Constant

$\mathrm{X} 1$ : Sex

$\mathrm{X} 2$ : Level of education

$\mathrm{X} 3$ : Length of business

X4 : The role of young farmers group

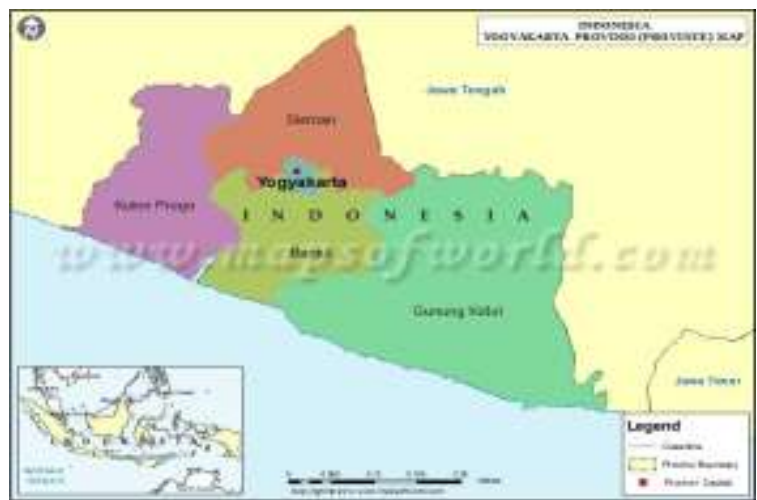

Figure 1. Map of The Special Region of Yogyakarta, Indonesia Source:https://www.mapsofworld.com/indonesia/provinces/yogyakarta.html

\section{RESULT}

A. Characteristics of Horticultural Young Farmers

Table 1 shows the characteristics of young horticultural farmers in this research:

TABLE 1: CHARACTERISTICS OF YOUNG HORTICULTURAL FARMERS

\begin{tabular}{|l|l|l|l|}
\hline Variable & Percentage(n= 300) & Mean & $\begin{array}{l}\text { Standard } \\
\text { Deviation }\end{array}$ \\
\hline Gender $(\boldsymbol{X} \mathbf{1})$ & & & \\
\hline Men & 83.3 & & \\
\hline Women & 16.67 & & \\
\hline $\begin{array}{l}\text { Education } \\
(\boldsymbol{X} \mathbf{2})\end{array}$ & & & \\
\hline $\begin{array}{l}\text { Primary } \\
\text { School }\end{array}$ & 1.33 & & \\
\hline Middle School & 13.33 & & \\
\hline High School & 74 & 12.07 & \\
\hline University & 11.33 & & \\
\hline $\begin{array}{l}\text { Length of } \\
\text { Business }(\boldsymbol{X} \mathbf{3})\end{array}$ & & & \\
\hline 1-5 years & 39 & 8.25 & 5,24 \\
\hline$>$ 5-10 years & 38.33 & & \\
\hline$>10-15$ years & 13.33 & & \\
\hline$>15$ years & 9.33 & & \\
\hline
\end{tabular}

Source: Primary Data Analysis (2019)

The results showed that men $(83.33 \%)$ had more activities in agriculture than women. Furthermore, the majority of young farmer education levels are High School/Vocational High School (74\%). While the average length of business of young farmers is 8.25 years.

\section{B. The Role of Groups and Their Effects on Horticultural Entrepreneurial Behavior}

The results of the validity and reliability test (using SPSS version 24) show that: all instruments are valid and reliable. The reliability test on variable group roles is 0,831 . Meanwhile in the entrepreneurial behavior variables: identification of opportunities (0.809), utilizing opportunities (0.860), developing businesses (0.861) and utilizing media new to businesses $(0.863)$. 
Table 2 shows the role of of young farmer group in this study.

TABLE 2. THE ROLE OF YOUNG FARMERS HORTICULTURAL GROUPS IN ENTREPRENEURSHIP

\begin{tabular}{|l|l|l|}
\hline Variable & Mean & SD \\
\hline The learning vehicle & 3.69 & 0.30 \\
\hline Building cooperation & 3.06 & 0.73 \\
\hline Building a network & 3.18 & 0.70 \\
\hline
\end{tabular}

Based on Table 2, the majority of farmers use groups as a vehicle for learning $(3,69)$. Efforts to build networks $(3.18)$ have been carried out by organizing group-based auction markets, building communication with extension agents, NGOs, and educational institutions. In addition to hold an auction market, efforts to build cooperation between farmers in groups $(3,06)$

Table 3 shows the mean results of each aspect of entrepreneurial behavior in this study was formulated as; the ability to identify business. opportunities, take advantage of business opportunities.

TABLE 3. ENTREPRENEURIAL BEHAVIOR OF YOUNG FARMER

\begin{tabular}{|c|l|l|l|}
\hline No & Indicator & Mean & $\begin{array}{l}\text { Standard } \\
\text { Deviation }\end{array}$ \\
\hline 1. & $\begin{array}{l}\text { Identification of Business } \\
\text { Opportunities }\end{array}$ & 3,48 & 0,56 \\
\hline 2. & $\begin{array}{l}\text { Utilizing Business } \\
\text { Opportunities }\end{array}$ & 3,05 & 0,68 \\
\hline 3. & Developing Businesses & 3,02 & 0.69 \\
\hline 4. & $\begin{array}{l}\text { Utilizing New Media for } \\
\text { Business }\end{array}$ & 3,02 & 0,72 \\
\hline \multicolumn{2}{|l}{} \\
Source: Primary Data Analysis (2019)
\end{tabular}

Based on Table 3, young farmers are sometimes seeking information about business opportunities $(3,48)$. The opportunity to take advantage of the business is sometimes done by exploiting the potential commodities, planting intercropping model. Utilizing business opportunities (3.05) done by marketing products that are on demand, and utilizing networking. Developing business behavior is sometimes done by improving quality and networking (3.02). Related to developing business, in the field can be found, chili farmers invest in the auction market, zallaca farmers with agro-tourism development, while onion farmers have not yet developed by the group. Onion farmers have recently developed private sales at tourists on beaches around the farm site.

Young farmers sometimes utilize new media to support their business. They have not optimize new media for business due to the lack of ability to manage new mediabased agricultural businesses and have not been able to find a potential market $(3,02)$. In the field, can be found that zallaca farmers sometimes utilize new media to support the development of agro-tourism.

\section{Effect of Determinant Factors on Horticultural Entrepreneurial Behavior}

TABLE 4. MULTIPLE LINEAR REGRESSION ANALYSIS OUTPUT (F) AND (R) OF DETERMINANT FACTORS ON HORTICULTURAL YOUNG FARMER ENTREPRENEURIAL BEHAVIOR

Model Summary

\begin{tabular}{l|l|l|l|l} 
R & R Sq & Adj R & Std. & Change Statistics \\
\hline
\end{tabular}

\begin{tabular}{|c|r|r|r|r|r|r|r|r|}
\hline & & Sq & $\begin{array}{c}\text { Error } \\
\text { of the } \\
\text { Est }\end{array}$ & $\begin{array}{c}\boldsymbol{R} \text { Sq } \\
\text { Chan } \\
\boldsymbol{g}\end{array}$ & $\begin{array}{c}\text { F } \\
\text { Change }\end{array}$ & df1 & df2 & $\begin{array}{c}\text { Sig. } \\
\boldsymbol{F} \\
\text { Cha }\end{array}$ \\
\hline 0,559 & 0,313 & 0,304 & 1,142 & 0,313 & 33,599 & 4 & 295 & 0,00 \\
\hline
\end{tabular}

a. Predictors: (Constant), rolegroup, sex, edu, lenght

Note: $*$ Significant at the $5 \%$ level

Source: Primary Data Analysis (2019)

From the analysis results (Table 4) it was found that, $\mathrm{R}$ value of 0.559 indicates the influence of independent variables (sex, education and length of business) on the dependent variable (entrepreneurial behavior). For the coefficient of determination (adjusted R Square) is 0.313, means that $31.3 \%$ entrepreneurial behavior is caused by sex, education and length of business. The remaining $68,7 \%$ are caused by other variables not examined. From the Anova table or F test (Table 4), the calculated $F$ value is 33,599 with level significance $\mathrm{p}<0.001$. This means that the independent variables has a real influence on entrepreneurial behavior so with this result means the regression model can be used to predict entrepreneurial behavior young horticultural farmers. Based on Table 5, independent variables have a significance value $\leq 5 \%$. It's means that partially independent variables have a real influence on entrepreneurial behavior. This is the result of the regression line equation: $\mathrm{Y}=2,425+(-0,111) \mathrm{X} 3$ $+0,532 \times 4$

TABLE 5. EFFECT OF DETERMINANT FACTORS ON HORTICULTURAL YOUNG FARMER ENTREPRENEURIAL BEHAVIOR

\begin{tabular}{|c|c|c|c|c|c|c|c|c|}
\hline \multicolumn{9}{|c|}{ Coefficients $^{\mathrm{a}}$} \\
\hline & \multirow[b]{2}{*}{ Model } & \multicolumn{2}{|c|}{ Unstand Coeff } & \multirow{2}{*}{$\begin{array}{c}\begin{array}{c}\text { StandCo } \\
\text { eff }\end{array} \\
\text { Beta } \\
\end{array}$} & \multirow[b]{2}{*}{$t$} & \multirow[b]{2}{*}{ Sig. } & \multicolumn{2}{|c|}{$\begin{array}{l}95,0 \% \text { Confidence } \\
\text { Interval for B }\end{array}$} \\
\hline & & $B$ & $\begin{array}{c}\text { Std. } \\
\text { Error }\end{array}$ & & & & $\begin{array}{l}\text { Lower } \\
\text { Bound }\end{array}$ & $\begin{array}{c}\text { Upper } \\
\text { Bound }\end{array}$ \\
\hline \multirow[t]{5}{*}{1} & \begin{tabular}{|l} 
(Constant) \\
\end{tabular} & 1,359 & 0,560 & & 2,425 & $0,016 * *$ & 0,256 & 2,462 \\
\hline & $\operatorname{Sex}(\mathrm{X} 1)$ & 0,182 & 0,183 & 0,049 & 0,996 & 0,320 & $-0,178$ & .0542 \\
\hline & $\begin{array}{l}\text { Education } \\
\text { (X2) }\end{array}$ & 0,009 & 0,031 & 0,015 & 0,292 & 0,770 & $-0,053$ & 0,071 \\
\hline & $\begin{array}{l}\text { Length of } \\
\text { Business (X3) }\end{array}$ & $-0,029$ & 0,013 & $-0,111$ & $-2,15$ & $0,032^{*}$ & $-0,056$ & $-0,003$ \\
\hline & $\begin{array}{l}\text { Role of the } \\
\text { Group (X4) }\end{array}$ & 1,302 & 0,120 & 0,532 & 10,83 & $0,000^{* *}$ & 1,066 & 1,539 \\
\hline
\end{tabular}

The model of the influence of each variable involving, sex and education level is not appropriate, the length of business is negative, while the role of the group has a positive effect on the entrepreneurial behavior of young horticultural farmers. Business experience has a significant adverse effect on entrepreneur behavior, meaning that the longer the farmer conducts agripreneur, the lower the level of entrepreneurial behavior. Each increase the length of business of 1 (one) point can decrease entrepreneur behavior by 0,111 points. The role of groups has a significant effect on entrepreneur behavior (Table 5). Each increase the role of the group of 1 (one) point can increase entrepreneur behavior by 0,532 points. Farmers who join the group will get a more developed opportunity than young farmers who have not participated in the group.

\section{DISCUSSION}

The characteristics of farmers, which include: educational level and length of business, can affect agricultural entrepreneurship, as [19] research. Sex does not affect the entrepreneurship, meaning that women have the 
same opportunity to do business. The development of technological innovation has facilitated agricultural activities as [20] research. Related to education, most of the young farmers graduated from High School. This data is in accordance with the Agricultural Census [21], which states that young farmers have a relatively high level of education than older farmers.

Business experience has a significant negative impact on entrepreneurial behavior. It means that the longer a farmer becomes an entrepreneurial, the more challenging to apply entrepreneurial behavior. The research shows that farmers who have long been in entrepreneurship have experience in cultivation and networks that have developed, and are running stably. Research with the similar results [22] reported that long experienced farmers were not interested in adding skills in utilizing new media. The research found that farmers who have long been in entrepreneurship have experience in cultivation or networks that have developed. The business has already running stable, thereby increasing the effectiveness of entrepreneurship more in line with personal needs, according to his own experience. Research with the same results was also stated by [3] [17] [22] [23] [24] which stated that older farmers had not been interested in increasing entrepreneurial skills related to information technology.

Interaction in groups allows the process of social learning as [13] [14] [25] [26]. Hariadi [27] states that strong interaction between members will allow many ideas to emerge so that the group can function to increase success as a unit of learning, cooperation, production, and business. The success of the social learning process can improve the ability to take advantage of technological innovation in agriculture.

The role of groups in this research are: a vehicle for learning, cooperation, and networking as opinion [27] [28]. The group as a vehicle for learning plays the highest role in supporting entrepreneurship. These results are consistent with [7] research which states that the role of groups in young farmers serves as a vehicle for mutual learning, cooperation in production and marketing, and building networks. Most young farmers feel the importance of the role of groups as a vehicle for learning rather than building networks and cooperation. in the field it was found that regular monthly meetings in groups can increase interactions for mutual learning. The result of the learning process is a change in behavior as a result of interactions with the environment (fellow young farmers).

The role of the group has a significant favorable influence on entrepreneurial behavior (Table 4). Bandura [19] explained that Social Learning Theory could occur through the stages of attention, retention, motor reproduction, and motivation. Learning from the experiences of other successful farmers or social learning through the interaction of young farmers is very useful in increasing entrepreneurial motivation as a state by [22] and entrepreneurial behavior [29] [30]. The role of agricultural extension workers in providing material and entrepreneurial assistance is also essential. In the field, it was found that the process of mutual learning can be seen in several innovations such as; the use of mulch to grow chilies, the use of drip irrigation in planting watermelons, and developing zalacca gardens to become agrotourism. This innovation is the result of a learning process that occurs in groups. More experienced farmers share their knowledge with other farmers. After seeing the success of farmers in the group, other farmers followed. The process of receiving innovation from each farmer is not the same depending on the belief or self-efficacy that changes in behavior can increase profits in farming.

The auction market as a joint marketing effort is the result of developing the role of groups in dealing with price fluctuations. Efforts to build a network that is done can increase farmers' bargaining in determining commodity prices as described by previous researches [6], [31] [28] [32] which stated that by groups, farmers will benefit and better bargaining prices. However, sales through the group-based auction market that has been running for a long time needs to be done innovation and network improvement in order to continue to develop a business. The role of group need to be strengthened by managing agricultural machinery and providing labor, as [33]. In the field, this effort has been made but is more personal. Also, cooperation in the provision of capital is also not optimal because of the lack of capital owned by the group. The group has tried to work with the bank to help overcome this capital problem.

The application of agricultural innovation is part of entrepreneurial behavior as a result of the learning process. Based on the opinion of [34] [35] [36] that the difference between entrepreneurial farmers and non-entrepreneurs lies in their creative and innovative abilities. This agricultural activity is characterized by entrepreneurial elements namely innovation, leadership, capital accumulation, managerial and courage to bear the risk as stated by [37] who argues that entrepreneurship is a creative and innovative ability that is used as a basis, tips and resources to look for opportunities to succeed. Related to utilizing new media for business, they promote their product using websites and other social media (Instagram, Facebook, WhatsApp). New media can help young farmers in shortening the marketing chain, so that selling prices can be better [17], [38], [39], [24].

\section{CONCLUSION AND RECOMMENDATIONS}

The results of this study are: 1) There is a significant influence on the role of groups on entrepreneurial behavior. Efforts that can be made are supporting the role of groups to learn from each other. These efforts can be made by organizing training, mentoring, and counseling following the needs and development of a young age. 2) Farmers who are longer entrepreneurs have to keep learning and are eager to improve their entrepreneurial abilities.

From the results of this study, the government is expected to encourage and facilitate group development as a vehicle to improve farmers' learning. Young farmers are expected to be more active in group activities, developing skills and innovation to become successful young entrepreneurs.

\section{REFERENCES}

[1] E. Y. Arvianti, M. Masyhuri, L. R. Waluyati, and D. H. Darwanto, "Gambaran Krisis Petani Muda Indonesia," Agriekonomika, vol. 8, no. 2, pp. 168-180, Oct. 2019, doi: 10.21107/agriekonomika.v8i2.5429.

[2] S. Wiyono, "Laporan Kajian Regenerasi Petani,” 2015.

[3] FAO, "Youth and Agriculture: Key Challenges and Concrete Solutions," Swedish, 2014

[4] A. A. Kutwa, W. N. Muhingi, and D. Kokonya, "Smallholder Rural Youth Farming in Kiambu County, Kenya," J. pf Cult. Soc. Dev., 
vol. 25, no. November, pp. 60-71, 2016.

[5] A. D. Nugroho, L. R. Waluyati, and Jamhari, "Upaya Memikat Generasi Muda Bekerja pada Sektor Pertanian di Daerah Istimewa Yogyakarta," J. Ilmu Pemerintah. dan Sos. Polit. UMA, vol. 6, no. 1, 2018.

[6] O. Anwarudin, S. Sumardjo, A. Satria, and A. Fatchiya, "Factors Influencing the Entrepreneurial Capacity of Young Farmers for Farmer Succession," Int. J. Innov. Technol. Explor. Eng., vol. 9, no. 1, pp. 1008-1014, Nov. 2019, doi: 10.35940/ijitee.A4611.119119.

[7] R. Elizabeth and S. Anugrah, "Economic Institution on Vegetables Farmers Community in Bali Province," Pus. Anal. Sos. Ekon. dan Kebijak. Pertan., vol. 134-146, 2014.

[8] S. S. Hariadi, Dinamika Kelompok (Teori dan Aplikasinya untuk Analisis Keberhasilan Kelompok Tani sebagai Wahana Belajar, kerjasama, Produksi, dan Bisnis). Yogyakarta: Sekolah Pasca Sarjana Universitas Gadjah Mada, 2011.

[9] Santrock, Life Span Development (Perkembangan Masa Hidup) Jakarta: Airlangga, 2012.

[10] S. W. Sarwono, Psikologi Sosial: Individu dan Teori Psikologi Sosial. Jakarta: Rajawali Press, 2010.

[11] K. Schneider, J. Pierson, J. Bugental, A. Montuori, and R. Purser, "Humanistic Psychology in the Workplace," in The Handbook of Humanistic Psychology: Theory, Research, and Practice, SAGE Publications, Inc., 2014, pp. 723-734.

[12] Albert Bandura, Social Learning Theory. New Jersey, 1977.

[13] T. A. Tran, H. James, and J. Pittock, "Social learning through rura communities of practice: Empirical evidence from farming households in the Vietnamese Mekong Delta," Learn. Cult. Soc. Interact., vol. 16, pp. 31-44, Mar. 2018, doi 10.1016/j.lcsi.2017.11.002.

[14] F. Schneider, T. Ledermann, S. Rist, and P. Fry, "Social Learning Processes in Swiss Soil Protection - The 'From Farmer - To Farmer' Project," Hum. Ecol., 2009, doi: 10.1007/s10745-009-9262-1.

[15] E. Kiptot, S. Franzel, P. Hebinck, and P. Richards, "Sharing seed and knowledge: Farmer to farmer dissemination of agroforestry technologies in western Kenya," Agroforestry Systems. 2006, doi: 10.1007/s10457-006-9007-8.

[16] O. Anthony, I. N. Nwachukwu, and O. U. Oteh, "Analysis of Entrepreneurial Behavior among Cassava Farmers in Ebonyi State, Nigeria," no. August 2015, 2014.

[17] G. John, P. D. Igwe, and S. R. P. D. Abiye, "ICT Entrepreneurship and Small Business Innovation: a Mechanism for Sustainability," Eur. J. Bus. Soc. Sci., vol. 3, no. 6, pp. 103-112, 2014.

[18] R. D. Pichardo, G. Mcelwee, R. Díaz-pichardo, C. Cantú-gonzález, P. López-hernández, and G. Mcelwee, "Entrepreneurship," no. February, pp. 89-116, 2012, doi: 10.1177/097135571102100104.

[19] E. Rasmikayati, I. Setiawan, and B. R. Saefudin, "Kajian Karakteristik Perilaku dan Faktor Pendorong Petani Muda Terlibat dalam Agribisnis pada Era Pasar Global,” Mimb. Agribisnis, vol. 3, no. 2, pp. 134-149, 2017.

[20] M. N. Agu, “Application of ICT in Agricultural Sector: Women's Perspective Monica," Int. J. Soft Comput. Eng., vol. 2, no. 6, pp. 5860, 2013.

[21] Badan Pusat Statistik, "Statistik Indonesia 2013," 2013

[22] Kabir, "Attitude and Level of Knowledge of Farmer on ICT based Farming,” Eur. Acad. Res., vol. 2, no. 10, pp. 13177-13196, 2012.

[23] S. Onakuse, "The Future of Subsistence Agriculture in The Rural Community of Uzanu , Edo State , Nigeria," J. Agric. Food Syst. Community Dev., vol. 3, no. 1, pp. 61-71, 2012.

[24] B. Dhaka and K. Chayal, "Farmers' Experience with ICTs on Transfer of Technology in Changing Agri-rural Environment," Indian Res. J. Ext. Educ., 2010.

[25] J. M. L. Laforge and S. M. McLachlan, "Learning communities and new farmer knowledge in Canada," Geoforum, 2018, doi: 10.1016/j.geoforum.2018.07.022.

[26] G. Leta, T. Stellmacher, G. Kelboro, K. Van Assche, and A. K Hornidge, "Social learning in smallholder agriculture: the struggle against systemic inequalities," J. Work. Learn., vol. 30, no. 6, pp.
469-487, Aug. 2018, doi: 10.1108/JWL-12-2017-0115.

[27] S. S. Hariadi, Dinamika Kelompok: Teori dan Aplikasinya untuk Analisis Keberhasilan Kelompok Tani sebagai Unit Belajar, Kerjasama, Produksi, dan Bisnis. Yogyakarta: Sekolah Pascasarjana Universitas Gadjah Mada, 2011.

[28] A. B. Raya, "Farmer Group Performance of Collective Chili Marketing on Sandy Land Area of Yogyakarta Province Indonesia," Asian Soc. Sci., vol. 10, no. 10, pp. 1-12, 2014, doi: 10.5539/ass.v10n10p1.

[29] M. Benjamin, "A Review of the Entrepreneurial Behavior of Farmers: An Asian-African Perspective," Asian J. Agric. Extension, Econ. Sociol., 2018, doi: 10.9734/ajaees/2018/39224

[30] J. Jones and S. Pratap, "An Estimated Structural Model of Entrepreneurial Behavior," Fed. Reserv. Bank Richmond Work. Pap., 2017, doi: 10.21144/wp17-07.

[31] J. Sulaksana, "The Process of Motivations Change in Farmer Groups,” J. Appl. Sci., vol. 11, no. 4, pp. 2500-2512, 2011.

[32] E. Rusdiyana, "Peran Pasar Lelang dalam Pemasaran Cabai di Kelompok Tani Lahan Pasir Pantai Kulonprogo, Yogyakarta," Caraka Tani J. Sustain. Agric., vol. 32, no. 2, pp. 1-8, 2018, doi: 10.20961/carakatani.v32i1.14666.

[33] Edoka, M. H. Igbokwe, and P. E. E. M and Adejo, "Constraints to Farmers' Labour Group Productivity in Eastern Kogi State, Nigeria," J. Agric. Ext., vol. 18, no. 2, pp. 68-75, 2014.

[34] L. Fred, "Employee engagement and manager self-efficacy," $J$. Manag. Dev., vol. 21, no. 5, pp. 376-387, Jan. 2002, doi: $10.1108 / 02621710210426864$

[35] S. Inwood, J. K. Clark, and M. Bean, "The differing values of multigeneration and first-generation farmers: Their influence on the structure of agriculture at the rural-urban interface," Rural Sociol., 2013, doi: 10.1111/ruso.12012.

[36] G. Mcelwee, “(PDF) Farmers As Entrepreneurs Developing Competitive Skills _ g.” 2006.

[37] R. Saragih, Berwirausaha Cerdas, Inspirasi Bagi Kaum Muda. Yogyakarta: Graha Ilmu, 2013

[38] D. K. Wambua, "Influence of Social Capital and Networks on Marketing Performance of Smallholder Grain Farmer Groups in Tharaka Nort h and Tharaka South Sub-Countries Kenya," Egerton University, 2017.

[39] K. Prayoga, Subejo, and A. B. Raya, "Young Farmers and Digitalization : From Price Taker to Price Maker," in International Graduate Student and Scholars Conference in Indonesia, 2019, no. 2011, pp. 181-188, doi: 10.18502/kss.v3i20.4935. 